\title{
Förförande historia - historiebruk i pornografi
}

\author{
Av Cecilia Trenter, Historia, Växjö universitet
}

\section{Historia - två kritiska synpunkter på historiebruk i pornografisk film}

Under 1980- och 90-talen utkom en rad böcker om historia och film som problematiserade förhållandet mellan historia, sanning och sammanhang på ett nytt sätt. Från att ha bedömt mediernas bruk av historia filtrerad genom sanningens raster övergick man till att studera film som medium för hur folk uppfattar historia.[1] I allt högre utsträckning har forskarna lämnat frågorna om historiska kostymdraman verkligen respresenterar en historisk verklighet eller ej för att förhålla sig till historiska spelfilmer som en genre bland andra filmgenrer. Bland böckerna som behandlar film och historiska handlingar finns Maria Wykes bok om historiebruk på antika teman i spelfilmer.[2] När Allan Klynne, doktorand i Antikens kultur- och samhällsliv, recenserade Wykes bok noterade han att hon utelämnat porrfilmer med antik tematik:

(...) som idag går att hitta i de flesta normalsorterade videobutiker. Här sitter den historiska rekvisitan bokstavligen löst; efter att ha fjantat omkring mellan vingliga pappkolonner låter aktörerna togorna falla av så att den nakna sanningen om antiken kan exponeras i minsta detalj. Hur denna genre påverkat masspublikens syn på romare och greker vore intressant att undersöka.[3]

Klynne sätter fingret på filmforskningens osynliga demarkationslinjer mot vissa av filmvärldens genrer till vilka pornografisk film måste räknas. Bland de pornografiska kostymfilmerna återfinns ett flertal filmer med tematik från just antiken, och gränserna mellan erotisk film och pornografi eller historiska sammanhang och historisk fetischism skulle onekligen vidga studierna av antiken på film. Den kognitiva koppling som Allan Klynne därtill gör - vad lär sig egentligen folk om antiken när de ser en pornografisk film med handling hämtad från en historisk epok? - lägger ytterligare en dimension till spörsmålet om historiebrukets giltighet i andra sammanhang än de legitima förmedliggskanalerna för historia (läroböcker, spelfilmer, dokumentärer, museer, vetenskap och populärvetenskap).

I andra änden av åsiktsspektrat placerar sig den brittiske journalisten Laurence O'Toole som i den omfattande boken Pornocopia: Porn, Sex, Technology and Desire pläderar för en mindre fördomsfull och mer positiv syn på pornografi, dess publik och branschens aktörer/aktriser. Han menar att de historiska kostymdraman där litterära eller historiska förlagor bestämmer handlingen är "dåliga" porrfilmer och motiverar ställningstagandet med att pornografi inte kräver en handling. [4]

Pornografiska filmer har i likhet med historiska draman kommit att definieras som en egen genre som är styrd av bestämda narrativa och visuella regler.[5] Många har uppmärksammat pornografins fetischistiska anslag där den visualiserade lustan gestaltas genom symboler, rekvisita och sammanhang. Jag kommer i följande artikel att ta upp dessa aspekter av historia i pornografi för att se hur visualiserad historia korrelerar till de krav den pornografiska genren ställer samt hur det kan påverka genus. Mitt material är Constance, en danskproducerad porrfilm för kvinnor.

\section{Vad är pornografi?}

"Jag kan inte säga vad pornografi är, men jag känner igen det när jag ser det" 
I de flesta försök till definitioner kläs karaktäristikan i porrmotståndarens ord. Det är inte endast en konsekvens av att porrmotståndare har ordet i offentligheten eftersom åsikten om pornografins förkastlighet varit politiskt korrekt i de flesta länder. Även när pornografi ska undersökas hamnar förbud och negationer i förgrunden. År 1986 tillsattes en kommission i USA , the Meese Commission, med uppdrag att kartlägga pornografins status och historia. I den slutgiltiga 1960 sidor långa rapporten handlade 16 sidor om själva aktiviteten pornografi medan de resterande 1944 sidorna behandlade lagstiftning och förbud.[6]

Pornografi kan definieras genom följande: "[...] its depiction of erections, penetration, oral-genital contact, ejaculation".[7] Pornografisk film/bild har av många betraktas som en realistisk samlagsskildring där mannens lusta står i centrum medan kvinnan (menar många) penetreras, förnedras och misshandlas. Till ofta citerade klassiker hör " Dachau brought into the bedroom"[8] i den våldsamma våg av protester som under 1980-talet följde på 1970-talets expansion på porrmarknaden. Retoriken och attityderna polariserades mellan dem som var för och emot. I kampen mellan gott och ont, rätt och fel formulerades pornografi som ljusskygg verksamhet, primärt riktad till heterosexuella män.[9]

Erotiken och pornografin ligger snubblande nära varandra. En del menar att det är två sidor av samma mynt men att erotik är något som tillskrivs kvinnlig lust medan pornografi är ämnad för män. En rad feminister har under 1990-talet pläderat för kvinnlig pornografi "Female erotica is pornography that's ashamed of itself".[10] Linda Williams, professor i filmvetenskap, menar att försöken att definiera pornografi och erotik leder till en snedvriden föreställning om vad som är bra och rumsren lust och vad som är förkastligt.[11] När kvinnlig sexualitet associeras med erotik medan männens förknippas med pornografi uppenbarar sig den kvinnliga lustan som mer naturlig, oanfäktad av våld och misantropiska anslag, medan männens sexualitet framställs som depraverad och brutal. Williams menar att den genusrelaterade uppdelningen mellan kvinnlig erotik och manlig pornografi i själva verket utestänger kvinnor från det pornotopia där fantasin och den självupptagna lustan är förhärskande.

Istället för att undersöka gränsen mellan manligt/ snuskigt pornografiskt och kvinnligt/erotiskt rumsrent tycker jag att Linda Williams ord klockrent träffar skillnaden: The erotic and pornographic interact in hardcore. The one emphasizes desire, the other satisfaction. Depending on who is looking, both can appear dirty, perverse, or too explicit.[12]

Pornografins allenarådande syfte är att åskådaren i grupp eller ensam ska upphetsas och tillfredsställas. Det finns inga andra mål med bilderna; inga estetiska värderingar, inga sociala normativa anspråk, inga direktiv om hur vi ska leva våra liv utan endast ett mål, utlösning.[13] Williams menar att pornografin inte ska läsas som sex utan som tal om sex. Hon exemplifierar med en komparation mellan den narrativa strukturen i hårdporrfilmer och musikaler. O’Toole gör liknande jämförelser och hävdar att vi utmärkt väl vet att människor inte dansar och sjunger i riktiga livet, men trots denna insikt underhåller ändå musikalerna genom musiken och handlingen. Samma nöje finner betraktaren i pornografi.[14] Linda Williams gör en mer ingående jämförelse mellan musikalen och hardcore pornografin. I båda fallen avbryts berättelsen av för handlingen omotiverade sångnummer (som i porren motsvaras av sexnummer) i ensamsång, duett, kvartett eller körsång, vilka motsvaras av porrfilmens olika ställningar och sexscener.[15] Jag tilltalas av Williams definition eftersom en närmare undersökning kräver en blick som inte utgår från pornografins kvalitet.

Utöver den funktionalistiska skillnaden mellan pornografi och erotik vill jag tillägga att i erotisk bild och text skapas sammanhang i vilka det sexuella underordnas estetiska normer och den övergripande berättelsens handling. Pornografins handling är underställd de sexuella aktiviteterna. Här spelar annat än handlingens inneboende logik in för att åskådaren ska ryckas med. 
Det som gör pornografiska filmer till pornografi är att sexscenerna är realistiska. Aktörerna och aktriserna gör "det" på riktigt, och denna realism går stick i stäv med den representativa och fiktiva handling som i övrigt kännetecknar hårdporr-genren.[16] I de få receptionstudier som gjorts av pornografins publik upprepas det gång på gång att njutningen erhålls på grund av att scenerna är visualiserade fantasier. Det finns inga belägg för att publiken tror att den pornografiska upplevelsen ska förverkligas i sin helhet. Genren appellerar till en drömvärld, en flykt från vardagens krav på ansvar. Därför är porrfilmer inte bundna av socialt realistiska berättelser. Kraven på autencitet ligger i att rekvisita och aktörer och aktriser lever sig in på ett övertygande sätt.

Pornografi kan dock aldrig helt definieras som en avspegling av människors fantasier eftersom, och detta är ytterligare ett särdrag för pornografi, porren endast levererar en del av varan. Definitionen är hämtad från porrbranschens egna led. Producenten Henri Pachard menar att pornografi ska förstås enligt "80/20-regeln"- porrprodukten står för 80 \% medan åskådarens egen fantasi fyller på de resterande 20\%.[17] Den pornografiska upplevelsen kan liknas vid en kopp pulverkaffe där pulvret är bilderna och åskådarens fantasi det oumbärliga vattnet.

Att skapa ett avstånd som ska överbryggas är avgörande för att de 20\% fantasi ska sammansmälta med de visualiserade $80 \%$. Distans-närhet blir ytterst viktigt för att en bild ska fungera pornografiskt optimalt. I pornografin före år 1800 skapades avståndet mellan publiken och modellerna genom att den avbildade voyeuren iakttog de älskande genom nyckelhål eller dörrspringor. I 1800-1900-talens pornografiska bilder lades avståndet mellan iakttagaren och bilden i rekvisita som sörjde för att betraktarens värld avskiljdes från ett utopia långt från vardagens påfrestelser. Verklighetsflykten ökade under boulevardtidningarnas tid - från ca 1915 - där målet för läsarna var att drömma sig bort och genom vackra kvinnor och dyrbart sceneri fly från vardagen till ett utopia, pornotopia,[18] där allt är möjligt. De fetischistiska effekterna blev ett alltmer avgörande redskap för att överbrygga avstånd.

Kombinationen av distans/närhet mellan bild och konsument samt fördelningen mellan konkreta visualiseringar och betraktarens egna fonder av fantasi gör att sammanhangen fungerar som mental brygga mellan bild och tanke. Sammanhangen konstrueras på olika sätt i olika pornografiska genrer. I herrtidningar som t ex Fib.aktuellt och Playboy skapas det pornografiska sammanhanget genom att utvikningsflickorna i text och bild berättar vem de är, vad de tycker om, vilka deras fantasier och drömmar är. Genom upplysningarna och de " bildliga bevisen" skapas en sfär där åskådaren kan ge sig hän åt fantasier.

\section{Fetischism och visualiseringen av manlig och kvinnlig orgasm}

Pornografi har alltså endast ett syfte: att väcka lust och ge utlösning. Ingenting annat. Det gäller således för producenterna att skapa ändamålsenliga produkter. Pornografins bildspråk är därför avhängigt av en symbolvärld och ett teckensystem som i varje detalj vägleder åskådaren i rätt riktning. Därför blir fetischism framträdande i pornografi. Fetischism betyder att ett föremål/bild fungerar kompensatoriskt. Jag tar utgångspunkt i den psykologiska och historiematerialistiska diskussionen om fetischism, inte minst för att dessa teoribildningar används i forskningen om pornografi/film och genus.[19]

Både Karl Marx och Sigmund Freud, fädrena till det moderna begreppet fetischism, betraktade fetischism som tecken på avsaknad av något. Marx menade att varufetischism utvecklades som ett kapitalismens redskap när människan alienerades till sig själv, sitt arbete och sina medmänniskor. Fetischen ersatte ett förträngt behov och Freud sökte bristen i psyket och sexualiteten. Båda menade att fetischen är kopplad till den visuella representationen; en sak, ett ting blir symbol för en äkta känsla eller ett sant värde. Båda utgick i sina arbeten från att det äkta/riktiga ersattes av bilden eller föremålet.

Jag vill gärna, i enlighet med genusforskningen, som särskilt behandlar hur film 
representerar verkligheten, hävda att de ekonomistiska ersättningsteorier som omgärdar fenomenet fetischism kan men inte nödvändigtvis behöver vara av ondo. Avgörande är hur fetischen används. Därtill menar jag även att abstrakta och för ögat inte synliga föremål, som exempelvis en berättelse, kan fungera som en fetisch. Historiska berättelser och minnesmärken, årtal och stiliserade förförståelser av historia kan fungera som en symbol eller ersättning för ett ideal/tillstånd/upplevelse som vår tillvaro inte tillåter oss att konkretisera.[20]

Filmen har mer än något annat medium betraktats som producent av fetischer. När tekniken möjliggjorde närbilder under 1920-talet, blev i synnerhet kvinnokroppen fetischiserad.[21] Närbilder av objekt, delar av kroppen eller scenografiska detaljer fungerade som en värld av tecken i ett alltmer ekonomiserat samhälle.

Orgasmen är det centrala objektet i pornografi. Mannens orgasm är den optimala symbolen för hur lust och ekonomi sammanfaller. Beteckningen för en synlig ejakulering kallas på internt språk money shot eftersom den manliga aktören får betalt i enlighet med om och hur väl han lyckas planera och placera utlösningen. I begreppet såväl som visualiseringen tydliggörs samhällets syn på sex och ekonomi.

Det eviga dilemmat för branschen är att visualisera den kvinnliga och för ögat betydligt mer svårfångade orgasmen.[22] Det förklarar den pornografiska modellens med ljud och rörelser "över-agerande" vid föreställd orgasm. Kvinnans lust måste visualiseras genom smink, stilettklackar, läder och leenden när mannen ejakulerar i hennes ansikte (vilket förekommer i stort sett all hårdpornografi). Detta är i korta drag hur genusforskningen betraktat fetischism, genus och lust i pornografi.

\section{Populärkulturens upprepningar och imitationer}

Populärkulturen kännetecknas av sin upprepande och imiterande funktion. Nya verk hänvisar öppet till tidigare, uppföljare till storsäljare i filmvärlden namnges genom nummer. Pornografin tillhör genom överdrivet utmärkande subkulturella drag otvetydigt populärkulturen. Därför kopierar pornografisk film ohämmat och öppet spelfilmer. När hårdporren slog igenom under 1970-talet lanserades en rad imiterande sexversioner under titlar som låg nära förlagan, t. ex. Flesh Gordon. Samma fenomen inträffade med den historiska filmen. En populär filmgenre sedan filmens gryning (i vanlig spelfilm) är den så kallade sword-and-sandal-genren med teman från antiken och biblisk historia.[23] I filmerna framställdes hjältar och hjältinnor från antiken i epos med sinnliga och våldsamma övertoner. I affischeringarna, framför allt under efterkrigstiden, avbildades skådespelarna i mer eller mindre visualiserad avkläddhet. Steget från den vågade spelfilmen till pornografi var troligen mindre i den antika periodens rekvisita än i spelfilmer med historiska teman som behandlar nationella trauman. Fellinis Satyricon följdes av en mjuksex-version och föranledde en omdöpning av förlagan till Fellinis Satyricon. Caligula är ett annat drama som blivit känt som ett pornografiskt spektakel snarare än som historiskt drama.[24] Andra budgetkrävande filmer med historiska anspråk var Captain Lust and the Pirate Women (1979) och Sodom and Gomorrah (1979). Under 1980-talet fick Mozartfilmen Amadeus en efterföljare i porrgenren där spelfilmens antagonister Mozart och Salieri i porrupplagans historia är såtaste vänner som delar om inte karriär så åtminstone kvinnor och sexuella upplevelser. Hänvisningarna till förlagan förekom explicit när porrfilmen Zorro presenterade västkusthjältens sexliv. I reklamen får vi veta att denna upplaga har "Mer stake än Banderas". Löftet, som i övrigt infrias i de följande bildsekvenserna, syftar på spelfilmens huvudrollsinnehavare Antonio Banderas.

Pornografins imitationer av spelfilmer med historisk tematik som förekommer framförallt under 1990-talet kan till viss del förklara uppsvinget för historisk visualisering i pornografi. Ytterligare ett faktum som motiverar all form av utklädningsrekvisita är pornografins "avkläddhet". I en undersökning av Fib. aktuellt visualisering av kvinnor och män visar Anja Hirdman att från att under 1970-talet ha visat nakna kroppar som fetischiserats i natursköna bilder och därmed laddats genom att utgöra en förlängning av själva naturen, 
ändras den sexuella representationen av femininitet till att visa halvklädda kvinnor. Den nakna kvinnokroppen räcker under 1980-talet inte längre till lockelse; smycken, klädesplagg och makeup blir en fetisch för nakenheten. "Dessa ting fylls med en egen sexuell symbolik för känslor och begär som förefaller alltmer fristående från den fysiska kroppen".[25] Härigenom får historisk rekvisita fetischistisk betydelse både genom att visualisera halvkläddhet och genom att referera till en historisk period som associeras med ansvarsfrihet eftersom de historiska rollerna är givna.

När hardcore-genren fått en decennielång historia dök imitationerna upp inom genren. Inom den historiska porrfilmen kommer det till uttryck i nostalgiska minnen. Gamla aktriser gör comeback och lanseras under 1990-talet i stil med 1940-tales filmprimadonnor. Scenerierna poängterar att filmens aktörer visualiserar gamla goda dagar i branschen förklädda i 1900-talets retrochica kostymeringar.[26]

Det är med andra ord inte historia som nyhetsskapande eller kartläggande fenomen som historieförmedlingen i pornografi ska jämföras med. Istället ska andra historiska filmer stå modell för jämförelsen. I slutet av min artikel kommer jag att diskutera mina resultat i förhållande till erotisk/historisk film i genren spelfilm.

\section{Historiebruk i pornografi - flykt, maskering och ansvarsfrihet}

Public history, offentlighetens historiebruk, definieras i termer av kollektivt minne. Den kollektiva hågkomsten har kallats "prosthetic memory" och hänvisar till vår förmåga att gemensamt minnas nationella trauman. Andra världskriget och motståndsrörelsens minnen har analyserats av danska och norska historiker. På liknande sätt har minnet av Vietnamkriget varit föremål för analys av amerikanska historiker.[27]

I pornografin, som hör till populärkulturens mer stiliserade genrer, används inte historisk rekvisita för att skapa ett gemensamt minne. Det förutsätter snarare historisk införståddhet, $\mathrm{t}$ ex om att antika kejsare missbrukade sitt folk, att 1700-talet var en sinnlig epok, eller att 1600-talets sjörövare var brutala. Konsumenten påminns om den historiska förförståelsen i texter på videons emballage eller vid försäljningen som ofta sker via internet. För att göra kunskapsfonden användbar får lärdomarna inte vara alltför specifika eller detaljerade utan måste fungera i form av stereotypa bilder av epokers särart som förstärker aktörernas framtoning. I motsats till en minneskultur eller en historiekultur fungerar dessa stiliserade sammanhang som "prompters of memory"[28] (utlösare av minne), där den historiska innebörden stannar vid en ofta anakronistisk och förenklad form utan hänvisning till ett historiskt sammanhang. Det fetischistiska anslaget strävar inte efter att skildra en större historisk eller samtida helhet som exempelvis ett monument har för avsikt.[29]

Historia liksom andra fora för historiskt berättande kan användas på olika sätt i pornografi. Den visuella presentationen lockar till historisk fetischism där enskilda föremål fungerar som symboler lösryckta ur sina historiska sammanhang och placerade i en sinnlig kontext. Den historiska kulissen används även för att maskera tabun - i en historiskt avlägsen tid är dagens syndighet inte alls någon synd. Historien används även för att lyfta fram vissa värden som generella och överhistoriska - vi är alla olika, men behovet av sex förenar oss.

Somliga epoker associeras mer till sensualism än andra. Historisk fetischism visar upp den rika världen. Det förekommer visserligen smuts och källarhålor i de historiska porrfilmerna men dessa utgör inte handlingens kärna utan fungerar som en kontrast till den huvudsakliga berättelsen. Smycken, kläder, arkitektur är hämtade från slott och palats. Detta gäller i synnerhet för filmer med antik koppling och filmer med hänvisning till 1700-talet.[30] Naturligtvis är de historiska filmernas utformning beroende av vem som regisserar. Regissörerna D'Amatos och Woodmans filmer är klassiska kostymfilmer som hämtar teman från kända personer eller epoker. Men historiebruket finns även med nostalgiska 1900-talsteman och i så kallad nazipornografi med sadomasochistiska inslag. 
Historiskt drama i pornografi betraktas varken som god historieförmedling eller bra pornografi. Ur pornografiskt hänseende kan det bero på en rad saker. En generell utmaning i historiska kostymdraman är att undvika att mannens kostymer blir förlöjligande. Visualiseringen är en av de svårare utmaningarna för kostymmakaren i det historiska dramat, eftersom åskådarens egna kläder som han/hon känner på sin egen kropp måste kunna relateras till bilderna på skärmen där aktörerna bär en historisk epoks mode.[31] Pornografi ska helst utlösa sexuell upphetsning och inte skratt. Därför kan det tänkas att val av perioder och rekvisita väljs efter manlighetsideal och inte efter andra principer.

Vanligtvis uppträder männen som den brutala och gärna skurkaktiga typen såsom pirat eller cowboy. Detta kan förklara varför kassetttexterna i presentationer försöker hitta en machoton för att övertyga om att dessa historiens aktörer var ena riktiga karlar. Den "goda" mannens maskulinitet räddas genom att klä honom i arbetarkläder med skjorta och hängslen som visualiserar kroppsarbete.[32] Kvinnodräkter är uppenbarligen inte lika problematiska. Silkiga strumpor, flortunna slöjor, smink och korsetter påminner om annan rekvisita i pornografi och får därför en dubbel konnotation som förstärker den sensuella upplevelsen.

I intervjuer med pornografins publik har det framkommit att autenticitet är viktigt för att budskapet ska nå fram. En oskuldsfull chearleader som låter kläderna falla och visar upp stora tatueringar förtar Lolita-känslan menar en kvinnlig betraktare.[33] Historiskt iscensättande provocerar kanhända genom att bli för overkligt i förhållande till vår tids föreställningar om sex. Tanken har förespeglat Linda Williams som menar att kostymdraman inte appellerar till utopiska fantasier vare sig handlingen utspelas i dåtid eller framtid eftersom dylika scenerier inte uppfattas som omedelbart relevanta för den moderna sexualiteten.[34]

Kanhända kan tilläggas att den historiska handlingen slår in öppna dörrar. Den vane betraktaren vet att pornografi innebär flykt från dagens krav. Därför verkar en historisk tematisering onödig eftersom betraktaren redan har accepterat reglerna när han/hon äntrar pornutopia. Ett så framträdande iscensättande som kostymdramat är blir detsamma som att erkänna ett främlingsskap med pornografins värld. Det är intressant att när pornografin under 1990-talet explicit gläntar på dörren för en kvinnlig publik genom framförallt dansk produktion (under försäljningsnamnet "Hjerteslag - porno for ham og hende") etableras fetischismen i just historisk miljö.

\section{"Constance" - pornografi för kvinnor}

I filmen Constance presenteras pornografi som är "anpassad för henne" enligt PR och presentationer. När filmen planerades användes en kvinnlig testpanel för att utröna kvinnors krav på pornografi. En framträdande åsikt var att lyfta fram sammanhang som förklarar de sociala relationerna och ger sexscenerna en logik. Den kvinnliga panelen efterfrågade bland annat, för att referera till ovan förda diskussion, en berättelse som närmare tangerar det jag kallar erotisk visualisering än pornografins $80+20$ princip. Regissören och manusförfattaren skulle alltså både skapa en distans-närhet-tematik och ett sammanhang som möjliggjorde förklaringar av sociala relationer. De valde en historisk tematik. Historiseringen sker dels genom tillbakablick i tiden, dels genom kostymer. Huvudpersonen läser sin mormor Constances dagbok. Bokens svårlästa handskrift ligger som en transparant slöja över bilden av den unga kvinnan som nyfiket följer sin mormors berättelser från svunnen tid. Vi får genom en berättarstämman höra om de erotiska lekar Constance beskriver i Lolas hus. Vem Lola är får vi aldrig veta, hon tycks vara Constances sexuella alterego och hennes hus är en lustens högborg där hon bor med sin hjärtevän och husslav. Det är Lola som fostrar Constance i hennes sexuella uppvaknande.

I andra scenen får vi se hur Constance (Anais) flyr över brinnande fält iklädd en vit empire-inspirerad klänning med tyll och slöjor. Hon har lockigt hår och är osminkad. Hennes kostymering påminner om spelfilmer med Jane Austen-motiv. Vi befinner oss genom kläderna vid sent 1800-tal eller sekelskiftet och de brinnande fälten symboliserar 
hennes brinnande lust.

Lola (Katja Kean) uppträder däremot i historisk kostym som hämtar detaljer från 1600talets tunga draperade kjolar, även om hennes make-up och frisyr inte följer samma linje. Det är intressant att den sexuellt frigjorda kvinnan uppträder i kostymer som associeras till äldre epoker medan Constance, i egenskap av mormor till läsaren, designmässigt placeras runt sekelskiftet. Betraktaren är, liksom filmens moderna kvinna som läser dagboken, närmare Constance i tid än den erotiskt erfarna Lola. Den förmodade kvinnliga betraktaren närmar sig pornografin via sekelskiftet och vidare till en tid höljd i dunkel. I likhet med andra historiska porrfilmer används inte historisk rekvisita i Constances sexscener. Kvinnornas underkläder är t ex i ett flertal scener i det närmaste vardagliga. Däremot iscensätts stämningen genom romantiska historiska objekt; vi ser en himmelssäng i vitt (Constances säng), ett altare i svart (som omtalas lustens altare) osv. I en scen när Lola rakar sig används ett gammaldags tvättfat och en spegel.

I en porrfilm för kvinnor blir mansbilden viktig. Det sades tidigare att kostymdraman har svårt att klä en man maskulint. Lolas vän (Marc Duran) bär byxor med hängslen och vit skjorta. Hans maskulinitet understryks av den drängkammare där han bor och besöks av Lola. På golvet ligger halm och kroppen exponeras när han tvättar sig i ett porslinstvättfat; Lolas man är kroppsarbetande och muskulös. I en karnevalscen där maskeringen är det centrala fetischistiska inslaget bär Marc Duran en venetiansk guldmask med förlängd näsa, en fetisch som understryker hans roll och potenta betydelse i filmen.

Husslaven (Niels Dencker) uppträder i nattskjorta och naken, inburad i en järnbur från vilken han endast släpps ut när Lola och hennes vänner ska leka. Styrkeförhållandet mellan Lola och hennes slav lyfts fram av bland annat kläderna: Lola vilar i en barockklänning på en divan medan hon vällustigt äter körsbär och samtidigt tillfredsställs oralt av en i nattskjorta klädd husslav. Scenerna är analoga med de antika teman där kejsaren tillfredställs på liknande sätt av sina kvinnliga slavar.

Skådespelarsammansättningen är genomtänkt i Constance. Betraktaren möter syndens näste genom Constance (spelad av Anais) som är finlemmad med liten byst och blek hy. Hennes manliga motsvarighet, husslaven är blek, spensligt byggd och framstår som ungdomlig genom bristen på kroppsbehåring. De utgör det oskuldsfulla paret, hon genom sin oerfarenhet och han genom sin asociala framtoning (han framstår genom sitt glada masturberande och älskande som lätt retarderad). Lola och hennes manliga vän har en annan fysik. Han är bredaxlad och hårig och hon är storbystad och solbränd.

Skådespelarnas fysik i kombination med rolltypen gör Lola och hennes vän till maskulinum (aktiva, erfarna, sadististiska) och husslaven Paw och Constance till femininum (passiva, naiva, masochistiska).

Constances roll som nyfiken och förförd är inte ny i porrfilmsgenrens persongalleri. Däremot möjliggör husslavens roll ett tänjande av den maskulina, manliga rollen. Den uppenbara tossighet som iscensätts och blir autentisk i den historiska miljön medger att han får bete sig "kvinnligt". I två scener masturberar han och slickar av sina fingrar vilket närmast är att betrakta som ett genrebrott i heterosexuell pornografi där manlig homosexualitet eller ens antydningar till detta är tabu.[35] Det är vanligtvis kvinnor som masturberar och smakar på sig själva, andra kvinnor eller män. Män rör och penetrerar endast kvinnor. I gruppsexscener vidrör aldrig männen varandra, sin egen eller någon annans säd. Analsex som är vanligt förekommande sker endast genom att kvinnan blir penetrerad (Constance innehåller inga analsexscener). Därför blir rollfördelningen i Constance ett genombrott i hardcore-pornografin eftersom maskuliniteten genom tydlig symbolik och historisk fetischism inte längre endast hör ihop med mannens roll.

\section{Genuskontrakt när historiska sammanhang skapas i pornografi och erotisk spelfilm}


Pornografisk film och bild ska inte betraktas som en realistisk sexskildring. Istället ska bilder och filmer läsas utifrån deras funktion som tal om sex. Underhållningsvärdet i pornografi är att hetsa upp och ge utlösning, och för att nå maximal upphetsning arbetar porrindustrin med sammanhangsskapande situationer som ska reta sinnet enligt 80+20\% definitionen. Detaljer och handling måste spela på betraktarens erfarenheter. Det sätt på vilket historia används i pornografi visar tydligt att historiska sammanhang inte styr val av rekvisita eller handling. Fetischism i egenskap av ting eller konkretiserade fragment i en berättelse medverkar till att skapa närhet-distans som ska överbrygga betraktarens erfarenhetsvärld och de visualiserade fetischerna på bilden/i filmen.

Den historiska fetischismen exotiserar, maskerar och medverkar genom sitt tidsmässiga avstånd till en distans där autenciteten avgörs av den dignitet som ett historiskt föremål signalerar. Vi vet att en man med gyllene lagerkrans och toga är en man med auktoritet; vi vet att en förgylld sal med speglar och statyer är Versailles namne; vi vet att en kvinna med svärd och svart lapp för ögat inte är att leka med. Vi kan skratta åt det, vi kan betrakta det som historieförfalskning men det fetischistiska värdet är inte att ta fel på.

Historiskt fetischistiska porrfilmer tematiserar underkastelse och ansvarsfrihet med stor auktoritet. Men vi måste övertygas om att fantasin kan aktiveras. En viktig ingrediens är att slippa göra valet. Enligt mitt förmenande bygger sadomasochism på en stiliserad lek där underkastelsen är ritualiserad och valfriheten utom räckhåll. I de historiska porrfilmerna fungerar den stiliserade underkastelsen och friheten från att behöva välja en ytterst central roll i den historiska kunskap som fetischiseras (kejsare var maktlystna, vilda västern var vild, karnevalens maskering depraverande osv). Ansvarsfriheten understryks i scener där rollerna implicerar underkastelse. Det gäller i synnerhet i filmerna. I antika scenarier placeras slaven i kejsarens våld. Både han, kejsaren, och hon, slavinnan, är determinerade i sina historiska roller. I sjörövarfilmen vet vi att hjältinnan och hjälten älskar varandra, trots denna brinnande kärlek kastas de ut i erotiska och ovalda situationer. Hon blir brutalt förförd av onda män och han blir bunden av en hord lystna kvinnliga pirater och därefter tvingad till sex av en kvinna från överklassen. Och de kan inte annat göra än att njuta. Därmed blir underkastelsen en fetisch för ett frånvarande oansvar som vi inte kan ta i våra vardagsroller. Historien sätter sin prägel på våra upplevelser trots uppenbara oegentligheter.

Däremot är handlingarna/bilderna inte konsekventa i förhållande till den utlovade historia som presentationer och tematik konnoterar. Vi får aldrig se eller ens höra om att de kvinnliga slavarna kastas till lejonen vid Caligulas hov. Tvärtom verkar de kvinnliga slavarna ytterst tillfredsställda med att tjäna kejsaren. Vi får aldrig se att piraterna är ondskefulla annat än när de binder huvudpersonerna för att sedan hetsa och reta och utan större motstånd locka fram både njutning och orgasm.

I pornografi blir den historiska ramen inte normativ i sitt fetischistiska anspråk. Istället fungerar historia som en dubblering av redan existerande fetischistiska anspråk, nämligen att skapa ett spelrum för fantasier. De historiska anslagen gör explicit inga försök att låta historien utgöra ett kitt i berättelsen; de onda visar sig vara goda (eftersom de sörjer för fysisk njutning) och de goda är inte trogna sina älskade utan har sex med diverse andra utan att känslor eller samvete påverkas. Den historiska tematiken är inte renodlade tidsresor. Bilderna avslöjar att vi fortfarande befinner oss i nutid, antingen genom ting som påminner oss om nuet eller genom att sexscenerna inte strävar efter historisk autencitet. Däremot fungerar den historiska fetischismen, liksom annan fetischism, som en möjlighet att töja genuskontraktet. I de fetischistiska scenerna stiliseras rollerna och i Constance ger de historiska ansatserna möjlighet att skapa nya kvinno- och mansroller i pornografi som inte sammanfaller med maskulinitet och femininitet.

Den erotiska boken med historisk tematik som vänder sig till en kvinnlig publik har en normativ karaktär av annat slag. I kioskromanen finns en sammanhängande narration där rätt och fel, orättvisa och rättvisa är avgörande för berättelsen. Här finns tydliga fetischistiska anslag som också problematiserar ansvarsfriheten genom underkastelse. Den historiska miljön får en avgörande betydelse för att skapa en scenografi som möjliggör 
fantasin. Huvudpersonen kämpar om sin älskade och får till sist, efter diverse intriger, sin utvalda. Här spelar ett annat behov av underhållning in. Vi får bekräftat att den goda och riktigt/ärligt handlande personen belönas till sist.

De historiska inslagen i kiosklitteraturen är lika lite historiskt korrekta som i porrfilmerna, varken rekvisita eller dialog har några som helst likheter med vad vi uppfattar som historiskt korrekt sammanhang.[36] De fungerar som tillflyktsort och fetischistiska inslag för att förtydliga och återberätta metaforen om underkastelse. I "kioskromanerna" dramatiseras underkastelsen enligt principen rättvisa, orättvisa och ond/god. I pornografin är underkastelsen relaterad till genrens funktion, att tillfredsställa sexuellt.

Den erotiska spelfilmen är återigen en genre som tematiserar underkastelse och sex. Att den erotiska filmen är bunden i tidens politiska kontext i en mer uttrycklig och normativ mening märks i amerikanska filmer som visades under 1980-talet när AIDS blivit en realitet.[37] I en erotiskt laddad spelfilm som t. ex. Farlig förbindelse bygger handlingen på att huvudpersonen inleder ett förhållande med en femme fatale. Filmens trovärdighet bygger på mannens skuldkänslor inför sin familj kontra hans dragning till den främmande kvinnan. Filmens autencitet ligger inte i älskogscenerna eftersom vi vet att huvudrollsinnehavarna Michael Douglas och Glenn Close spelar teater när de valsar runt på husets alla köksbänkar i ohämmad älskog. Igenkännandet ligger i det sociala sammanhang älskogsscenerna ingår och som driver handlingen fram, nämligen skulden och de obönhörliga konsekvenserna samt strävan efter att ordna kaoset efter det erotiska mötet.

Till detta kan man lägga att amerikanska spelfilmer under samma tid behandlar den amerikanska nationen ur ett nytt nationalistiskt perspektiv. Den traditionella nationen definierad genom ras och historia byts ut mot ett mångfacetterat och etniskt pluralistiskt nationsbegrepp.[38] Men nationen står i centrum, och i den erotiska filmen blir därför ofta sexualiteten och attraktioner ett tacksamt ämne att behandla hotet om nationell splittring genom. Detta finns i nutidsorienterade filmer som nyss nämnda Farlig förbindelse, där huvudpersonens otrohetsaffär leder inte endast till skuldkänslor utan till en direkt katastrof för familjen (nationen). I Firman återfinns samma tematik; den manliga huvudpersonens snedsteg med en okänd vacker kvinna i en tillfällig sexakt visar sig få ödesdigra konsekvenser eftersom det pornografiska mötet är planerat och fotograferat av fienden. Misstaget tematiserar den svage mannens ack så mänskliga men dock så fatala misstag som får ödesdigra konsekvenser. Till sist underkastar han sig rättvisan och gör det riktiga valet.

Den erotiska historiska filmen från 1980- och 90-talen tematiserar tydligt mänsklighetens dekadens och vikten av att välja ansvaret. Den historiska handlingen förtydligar självklarheten. Det är lättare att förstå varför 1800-talets snäva sociala regler möjliggör förbud mot opassande attraktioner som i Oskuldens år där huvudpersonerna dras till varandra men måste uppge passionen. I Farligt begär får vi i 1700-talets Frankrike följa den cyniska och sinnliga markisinnan och hennes lek med oskulden och erotiken tills ödet sätter stopp för hennes planer och hon straffas i filmens slut. Det finns mycket att tillägga om erotisk thriller/spelfilm, men här vill jag hårdra poängen till följande 1) handlingen bygger på att det goda segrar 2) personerna betalar ett högt pris för att nå målet genom att uppge sin självupptagna passion/erotiska längtan. Sexualiteten blir en fetisch för det nationella sveket och ansvaret.

I den erotiska filmen är sammanhanget väldefinierat och sexscener och erotik får en tydlig roll i en större berättelse. Filmernas beroende av en övergripande och sammanhängande narration hänger ihop med det sätt på vilket vi tittar på spelfilm. I motsats till pornografin som avnjutes bitvis ser vi spelfilmer i sin helhet, med en början och ett slut. Många filmer under 1990-talet tematiserar erotik och gränsen mellan erotik och pornografi är stundtals flytande. Men i synnerhet i den historiska erotiska filmen är rollfördelningen inte ny; kvinnan är symbolen för nationen och mannen är den handlande aktören.[39] Sensmoralen är att uppge den egna njutning och sörja för att nationen/familjen förblir skyddad och intakt. I pornutopia är syftet det rakt motsatta; genom flykt och maskering där nuet och betraktaren förankras i historisk miljö aktiveras ett fetischistiskt förhållande till en värld av 
lust och egocentrisk njutning som realiteten inte erbjuder.

\section{(C) Cecilia Trenter}

[1] Landy, Marcia: "Introduction", i The Historical Film: History and Memory in Media, Landy Marcia (ed.), New Brunswick/New Jersey 2001, s. 5.

[2] Wyke, Maria: Projecting the Past: Ancient Rome, Cinema, and History, NY/London 1997.

[3] Klynne, Svenska Dagbladet 1998-08-13.

[4] O'Toole, Laurence: Pornocopia: Porn, sex, technology and desire, London 1999.

[5] Se t. ex Williams, Linda: Hardcore: Power, Pleasure and the 'Frenzy of the visible', (1988) 1999; O'Toole, Laurence 1999.

[6] Hunt, Lynn: "Introduction: Obscenity and the origin of Modernity, 1500-1800", i The invention of pornography: Obscentity and the origins of Modernity. 1500-1800, New York 1993, s. 11.

[7] O'Toole 1999, sid. 10.

[8] Andrea Dworkin: Pornography: Men possesing women, London 1981.

[9] Trots att attityden av olika skäl har ändrats under 1990-talet hänger hotbilden kvar som en skugga. Sökordet "pornografi" i Libris sammanstrålar med sökord som "incest", "våldtäkt" vid sidan av vetenskapliga termer som "psykologi", "vetenskapshistoria" och "sexologi".

[10] Charlotte Raven här citerad ur O'Toole 1999, s. 7.

[11] Williams 1999 sid 6ff, sid. 18ff. Michel Foucault har i sin berömda studie av sexualitetens historia hävdat att just detta behov av att lyfta fram och genom tal om förbud synliggöra sexualiteten är emblematiskt för det västerländska modernistiska samhället, Foucault, Michel: Sexualitetens historia: Viljan att veta, Stockholm 1976.

[12] Williams 1999 s. 277. Carol Clover har bland andra gjort liknande definitioner och förklarat pornografins "pinsamhet" i dess raka syfte att tända och tillfredsställa, Clover Carol J.: Introduction, i Dirty Looks, Women, pronography, Power, Gibson, P. C.\& Gibson R. (ed.) ,Worcester 1993.

[13] Därmed inte sagt att pornografin inte kan få en annan social funktion utanför genrens egen form.

[14] Liknelsen är gjord av en av O'Tooles intervjuade personer, O' Tooles 1999 s. 23.

[15] Williams 1999 s. 131 ff.

[16] Kipnis, Laura: "Pornography", i The Oxford Guide to Film Studies, Hill John \& Gibson Pamela Church (ed.), Oxford University Press 1998, s. 156.

[17] Tankegångarna är hämtade från porrfilmsproducenten A. R. StoneO'Toole 1999 s. 16. [18] Uttrycket "pornotopia" är myntat av Steven Marcus i studierna av den viktorianske boksamlaren Henry Spencer Ashbee och syftar på den mekaniserade och hedonistiska drömbild som bland annat lanserades av Markis de Sade, se Marcus, Steven: The other Victorians: A study of Sexuality and Pornography in Mid-Nineteenth-Century England, New York 1974, s. 45.

[19] Se t. ex. Mulvey Laura:Fetischism and couriosity, London 1996, Linda Williams 1999 m.fl.

[20] Trenter, Cecilia "I mötet med minnet. Historiekulturer i Skandinavien" i Historisk tidskrift: 22002.

[21] Laura, Mulvey 1996.

[22] Williams 1999, O'Toole 1999 sid. 24.

[23] Smith, Gary A.: Epic films: casts, Credits and Commentary on over 250 Historical Spectacle Movies, sid. XV, London.

[24] Filmen utkom 1979 initierad och finansierad av Penthousemogulen Bob Guccione och med bland annat Peter O'Toole i skådespelargalleriet.

[25] Hirdman Anja: Tilltalande bilder: Genus, sexualitet och publisyn i Veckorevyn och

Fib aktuellt, Stockholm 2001, s. 243-44.

[26] Se t. ex. Ginger Lynn är tillbaka: primadonnan 2000.

[27] Bryld, Claus \& Warring, Anette : Besaettelsetiden som kollektiv erindring, Roskilde, 1999. Begreppet Prosthetic Memory är lånat från Landsberg och hennes studier av 
Vietnamfilmers betydelse för det kollektiva minnet, Landsberg, Alison: Prosthetic Memory: The Logic and Politics of memory in Modern American Culture, Chicago 1996. [28] Ansökan till danska grundforskningsrådet april 2001 "Cultures of Memory research Centre", Bernard Eric Jensen \& Anette Warring.

[29] Ett exempel är den okände soldatens grav som visualiserar ett nationellt sammanhang, se Anderson, Benedict: Den föreställda gemenskapen, Göteborg 1993.

[30] De historiska kostymfilmerna tillhör den pornografiska genren "luxury and gloss" , O'Toole 1999 s. 101.

[31] Tashiro, C. S.: Pretty Pictures: Production Design and the History Film, Austen: Tex. $1998 \mathrm{~s}$.

[32] Se till exempel Rudy Valentin.

[33] O'Toole 1999.

[34] Williams 1999.

[35] Williams 1999.

[36] Se t. ex. Queckfeldt, Eva: Om kiosklitteratur med historiskt motiv, i Makten över minnet. Historiekultur i förändring red. Aronsson, Peter. 2000.

[37] O'Toole 1999.

[38] Burgoyne, Robert: Film nation: Hollywood looks at U.S. history, Minneapolis/London 1998.

[39] Jämför med svensk 1930-tal där familj, kärlek och passion regisseras enligt en önskad bild av folkhemmet, Qvist, Per-Olov: Folkhemmets bilder: Modernisering, motstånd och mentalitet i den svenska 30-talsfilmen, Studentlitteratur/Lund 1995. 